\title{
ANALYSIS OF THE OPPORTUNITIES TO IMPLEMENT THE BIZ-TRIZ MECHANISM
}

pages: $19-30$

\author{
DOROTA CHYBOWSKA, LESZEK CHYBOWSKI, \\ BOGUSZ WIŚNICKI, VALERI SOUCHKOV, SREĆKO KRILE
}

Corresponding author:

\begin{abstract}
A B S T R A C T
Aiming to strengthen cooperation between scientific entities and enterprises and to overcome related obstacles, the authors propose to create a mechanism of incentives called BIZ-TRIZ, which is an abbreviation for "TRIZ for Business". This mechanism is used to support cooperation between scientific entities and companies. Close cooperation is achieved by implementing R\&D\&I services, which is the responsibility of the scientific unit operating for the benefit of the companies involved. Research services are used together with the scientific instrument that reflects achievements in the modern theory of innovative problem solving (TRIZ). The analysis was made using the Maritime University of Szczecin and SME-type companies as an example. This paper describes the basic assumptions concerning the implementation of the BIZ-TRIZ mechanism. Also, it presents the use of SWOT analysis, needs/stakeholder analysis and risk analysis for the implementation of the BIZ-TRIZ mechanism. The paper describes preventative actions for the most important implementation risks and discusses the results of the analyses. Finally, it introduces the main conclusions regarding the purpose of implementing the BIZ-TRIZ mechanism.
\end{abstract}

KEY WORDS

Theory of Inventive Problem Solving (TRIZ), BIZ-TRIZ mechanism, SME sector, R\&D\&I services, feasibility analysis

DOI: 10.2478/emj-2019-0008
Dorota Chybowska

Maritime University of Szczecin, Poland e-mail: d.chybowska@am.szczecin.pl

Leszek Chybowski

Maritime University of Szczecin, Poland e-mail: I.chybowski@am.szczecin.pl

Bogusz Wiśnicki

Maritime University of Szczecin, Poland e-mail: b.wisnicki@am.szczecin.pl

Valeri Souchkov

University of Twente, Netherlands e-mail: valeri@xtriz.com

Srećko Krile

University of Dubrovnik, Croatia e-mail: srecko.krile@unidu.hr

\section{INTRODUCTION}

The annual Innovation Union Scoreboard is one of the instruments that enable the determination of the skilful use of knowledge for the economic development of EU member states, including Poland. This measure was introduced by the European Commission to evaluate achievements in the broadly described area of innovation of the EU Member
States. Despite a significant financial injection from the EU's structural funds, Poland demonstrates a minimal upward trend in the value of the innovation indicator. Poland is still about $40 \%$ below the EU-28 average and ranks 4th from last among EU countries (Chybowska, Chybowski \& Souchkov, 2018a; European Commission, 2018). To rely on the knowledge and overcome the average income trap, 
the Polish economy must possess national knowledge resources (Chybowska, Chybowski \& Souchkov, 2018a; Chybowski \& Idziaszczyk, 2015c), as well as a developed R\&D base and technologies and products capable of entering many markets. This knowledge should be adequately transferred from the scientific sector to the economy (Powell \& Snellman, 2004).

The process of commercialisation of research results has been visualised in Fig. 1. The model shown in Fig. 1a is typical for economies with a developed $\mathrm{R} \& \mathrm{D}$ market and should be considered a proper model of the cooperation between an enterprise and a university (business-university). Characteristically, the company and the university work hand in hand to develop the potential technology. For companies, the first phase, which the world of science calls the research phase, is, in fact, a pre-investment phase (Chybowska, Chybowski \& Souchkov, 2018b). From the perspective of a university, the second phase involves the preparation of a prototype and the validation of its operation as well as the removal of obstacles which could not be predicted during the research phase. In the case of enterprises, this phase is an investment phase. The culmination of the cooperation between science and business is the exploitation (operational) phase when a technology/device etc. is introduced to the market. As demonstrated, the entire process of converting research results into a product that can be launched onto the market may take more than ten years.
The model in Fig. $1 \mathrm{~b}$ represents the situation, in which the main players - the scientists and entrepreneurs of the R\&D market in Poland - currently operate. Due to the impaired cooperation between the private and scientific sectors, the latter does not verify the usefulness of the achieved results for the benefit of the potential recipient. This means that the recipient would have to repeat the research phase (for pre-investment) before purchasing the research results, thus prolonging the whole process. In other words, the world of science produces a certain technology and then looks for investors to bring it to the market. The investor will not take a financial risk and will not invest in untested technology; so, in the bestcase scenario, there will be a regression to the previous step, and in the worst case, there will be zero cooperation. It should be noted that Polish enterprises are mainly focused on the acquisition of already finished foreign technological solutions, primarily using low labour costs as their competitive edge. SMEs constitute $99.8 \%$ of companies operating in Poland, employing $2 / 3$ of the workforce, with over $45 \%$ of them operating in the service sector and $30 \%-$ in the commercial sector (Chybowski \& Idziaszczyk, 2015a).

Observations of the relations between science and business show three main barriers to the implementation of shared projects:

- The lack of financial resources on the part of SME-type companies to solve complex internal

a)



Fig. 1. Commercialisation of research results: a) the correct way, typical for knowledge-based economies, b) shifted in time, currently occurring in Poland

Source: author's elaboration based on (Półkoszek, 2016). 
problems, which requires the involvement of many different specialists at the same time and the coordination of such activities:

- The anxiety among scientists arising from the confrontation between their scientific research and the market reality ("research utilitarianism test");

- The inability to innovate in SMEs and the conviction that innovation occurs only in corporations and large companies.

Aiming to strengthen the cooperation between scientific entities and enterprises and to overcome related obstacles, the authors propose to create a mechanism of incentives called BIZ-TRIZ, which is an abbreviation for "TRIZ for Business". The analysis was made using the Maritime University of Szczecin and SME-type companies as an example. This mechanism is based on services provided for these companies by researchers solving, complex internal production/organisational/technical problems, among other things, using the TRIZ methodology (Boratyński, 2013).

The article is structured as follows: the first chapter provides a literature review on the subject and outlines the basic assumptions and objectives for the use of the methods attributed to the Theory of Innovative Problem Solving for closer cooperation between academic entities and enterprises. The following chapter presents a SWOT matrix to elaborate on the results of the analysis into the strengths and weaknesses arising from the application of the BIZTRIZ mechanism. The analysis was based on the results of the survey and the literature review. The results of the SWOT analysis showed significant benefits from the application of the BIZ-TRIZ mechanism. This required a needs analysis of the individual stakeholders implementing the BIZ-TRIZ mechanism. The stakeholder analysis is described in the third chapter. Not only did the selected entities have the relevant resources for the implementation of the TRIZ mechanism, but the implementation of the BIZ-TRIZ mechanism was also highly cost-effective in their case. Subsequently, based on the obtained results, the risk associated with the implementation of the BIZ-TRIZ mechanism was analysed. The results of this analysis encompassing 12 primary risks are presented in Chapter 4; the risks are quantified and illustrated using a risk matrix. For particular risks, actions to prevent and minimise them are proposed. Next, the obtained results are discussed as well as their interconnections and the advisability of implementing the BIZ-TRIZ mechanism. Finally, the article is summarised, providing general conclusions.

\section{LITERATURE REVIEW}

TRIZ is the Russian acronym for "теория решения изобретательских задач", which can be translated as the Theory of Inventive Problem Solving (Cempel, 2013; Chybowski \& Idziaszczyk, 2015b). It is a methodology that was developed by Russian inventor Genrich Altshuller, who started working on it in 1946. Altshuller continued developing TRIZ until his death in 1998. Further development of TRIZ was carried out by his successors at the TRIZ School of Inventions (Cempel, 2013).

TRIZ is currently one of the most effective methodologies for so-called systematic innovation (Chybowski \& Chybowska, 2016a). TRIZ is based on a solid empirical foundation of inventiveness, technical knowledge and the achievements of applied sciences (manufacturing engineering, machine construction and operation, materials engineering, technical physics, etc.). TRIZ relies on the use of tools to create and develop innovative technical and organisational solutions based on "hard" scientific and technical knowledge (Chybowski \& Idziaszczyk, 2015b). The tools include functional analysis, trimming of systems, the contradiction matrix, the algorithm of innovative task solving (ARIZ), function-oriented analysis (FOS), transfer of functions, the $S$ curve, "inventive tricks", i.e. removing technical, physical and organisational contradictions, Su-Field analysis (substance-field models), programs and databases for patent information processing and many more (Chybowski \& Chybowska, 2016a; Chybowski \& Chybowska, 2016b; Chybowski, Gawdzińska \& Przetakiewicz, 2017; Chybowski, 2018). From a scientific point of view, TRIZ builds on the achievements of systems theory, invention theory, bionics and psychology, and is constantly being improved.

Owing to the wide application of TRIZ for real problem solving and its local popularity, this methodology has contributed significantly to the economic development of such countries as Japan, South Korea and the USA (Chybowski \& Idziaszczyk, 2015c; Yatsunenko \& Karendał, 2016). In terms of the number of trained TRIZ specialists, South Korea is the leader, which, in large Korean companies, significantly translates into the number of patents obtained by large South Korean companies and the value of their brands (Fig. 2). 

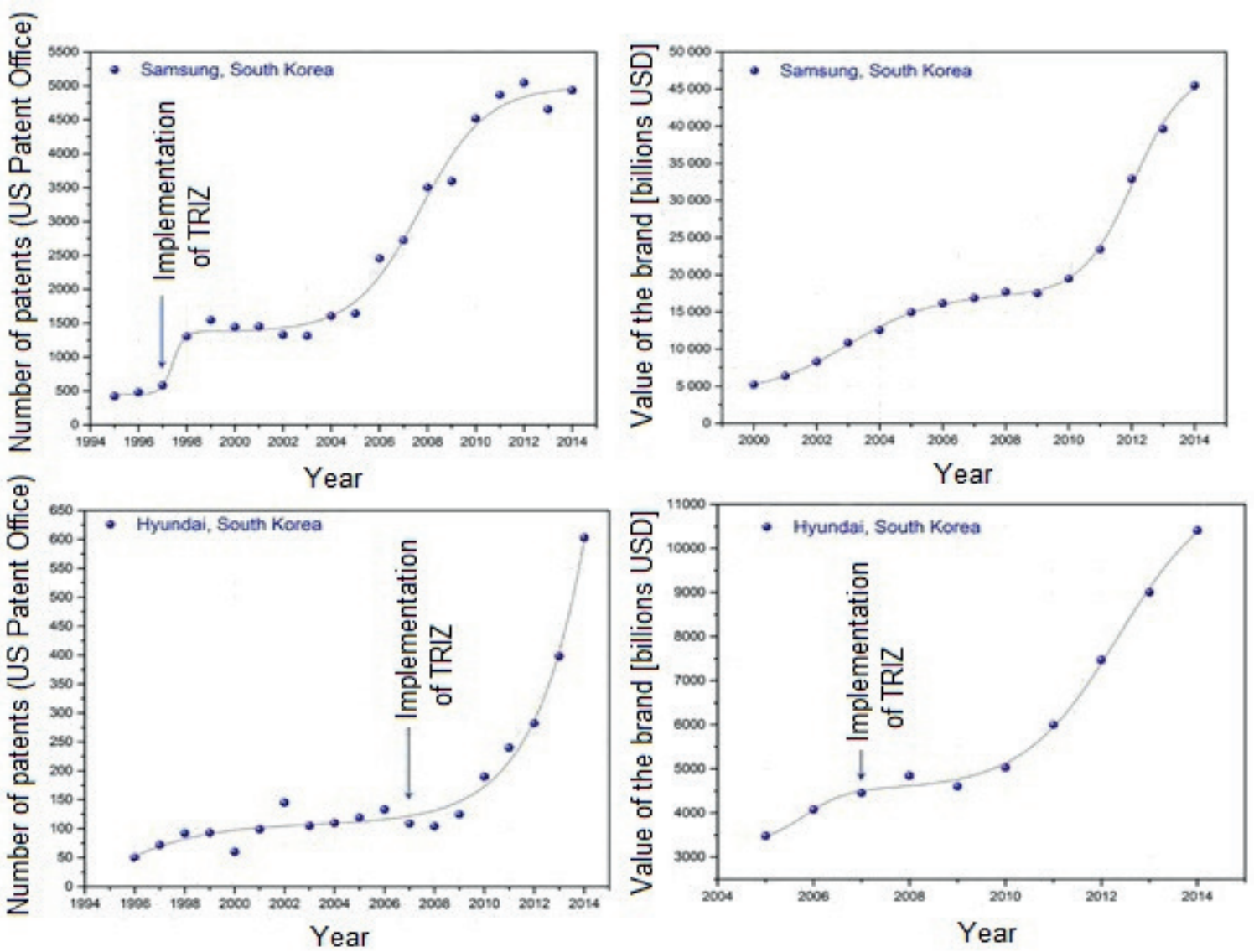

Fig. 2. Increase in the number of companies' patents showing the correlation with the increase in brand value after implementation of TRIZ based on the example of Samsung and Hyundai

Source: (Yatsunenko \& Karendał, 2016).

According to the cited statistics, TRIZ can act as a bridge between science and the economic environment, improving the effectiveness of their cooperation. It provides researchers with a solid foundation and tools enabling them to use the existing advanced technical knowledge to create practical solutions for enterprises. The solutions help enterprises gain a competitive advantage in the market by introducing new products or eliminating existing production/ organisational/technical problems. The authors believe that the idea of using TRIZ to promote innovation among scientists and entrepreneurs will contribute to the emergence of good practice for cooperation between science and business entities, new technological solutions, as well as creating opportunities for their commercialisation (Souchkov, 2015; Souchkov, 2017; Souchkov \& Roxas, 2016). An additional advantage arising from the implementation of the BIZ-TRIZ mechanism is cooperation in the creation of strong links between science (specialist knowledge), innovation (new solutions through TRIZ) and SMEs (recipients and co-participants in the creation of innovations). The BIZ-TRIZ mechanism has the following specific objectives: increasing the competence of university team members working in the field of inventive methods, systematically creating innovations using training, the (optional) process of certification in the field of the Theory of Innovative Task Solving (TRIZ) according to the MATRIZ guidelines, and participating in thematic conferences and/or study visits to TRIZ educational centres and/ or companies using TRIZ with the aim of creating innovative technical solutions.

The literature analysis enabled the identification of the possibility of using the TRIZ methodology to bridge the gap that is presented in the introduction, i.e. the lack of proper cooperation between scientific entities and enterprises. According to the results of the literature analysis, the TRIZ methodology effectively contributes to the growth of enterprises and entire economies. The authors decided to adopt this methodology in Poland by applying and adapting it to the local circumstances, which the authors called the BIZ-TRIZ mechanism. The main aims of this mechanism are: 
- To develop effective mechanisms of cooperation between the Centre for Technology Transfer (CTT), university research teams and the private sector;

- To establishing multidisciplinary university working groups as well as to create a unique scientific workshop as a result of the research and adaptation of TRIZ tools to the specific fields covered by project team members and the case study;

- To implement research services for SMEs aimed at solving complex production, organisational and technical problems.

\section{STRENGTHS, WEAKNESSES, OPPORTUNITIES, AND THREATS OF THE BIZ-TRIZ IMPLEMENTATION}

To determine the chances of implementing the BIZ-TRIZ mechanism, the authors analysed the possibilities and obstacles relating to the specifics of the Polish operations of the main players (scientists, SME employees and staff of the Centre for Technology Transfer) and the current market realities (political and economic environments). This analysis is based on the results of the survey and the literature review that were conducted earlier. A summary of the analysis in the form of a SWOT (Strengths, Weaknesses, Opportunities, and Threats) matrix is presented in Tab. 1.

The primary strengths related to the implementation of the BIZ-TRIZ mechanism in the analysed university are the growing prestige, the improving staff competence, the expansion of the research base and the support of the university authorities given to the staff. The weaknesses of the BIZ-TRIZ implementation are still the low popularity of heuristic methods, the lack of sufficient knowledge of TRIZ, and the lack of the habit among scientists to use it. The opportunities include the growing popularity of heuristic methods in recent years, increasing competition between enterprises and emerging, increasingly more complex, technical problems. The main threats are the lack of adequate resources necessary to implement the BIZ-TRIZ mechanism, the lack of awareness of the possibility to improve the situation in the companies as well as communication problems.

\section{NEEDS/STAKEHOLDER ANALYSIS}

The results of the SWOT analysis showed the significant benefits of the application of the BIZ-TRIZ mechanism, which required an analysis of individual stakeholder needs while implementing the BIZ-TRIZ mechanism. The selected entities had the relevant resources for the implementation of the TRIZ mechanism and, at the same time, the implementation of the BIZ-TRIZ mechanism was highly cost-effective in their case. A stakeholder analysis identified their needs in great detail. To assess the impact of BIZTRIZ implementation on specific recipients, the main stakeholders, directly related to the BIZ-TRIZ implementation, were identified and summarised in Tab. 2.

Another analysis was made of the impact that the identified stakeholders might have on the implementation of the BIZ-TRIZ mechanism and whether they were interested in the result of the mechanism. Thus, the aim was to determine whether the key stakeholders for the implementation of the BIZ-TRIZ mechanism would be interested in the implementation and whether its results would be a good fit with their needs. The classification of stakeholders based on their potential impact on the implementation of the BIZ-TRIZ mechanism and the direct benefits resulting from the implementation are given in Fig. 3.

The most important aspects for the implementation of the BIZ-TRIZ mechanism are the stakeholders that are located in the upper right quadrant of the matrix. Not only do they have a high potential to make an impact but, at the same time, due to the benefits of implementing BIZ-TRIZ, they also would be seemingly interested in implementing the BIZTRIZ mechanism as it is directly related to meeting their needs, which in particular concerns the key stakeholders:

- $\quad$ I7 - scientists from the Maritime University of Szczecin will acquire the competences necessary to create innovations using systematic methods (TRIZ), they will establish cooperation with companies, and will solve real problems the companies have, thus they will have to overcome the fear of conducting research for the recipients of SMEs (research for business);

- I8 - companies from the SME sector will gain an opportunity to solve their own technical and organisational problems, thus increasing the market competitiveness of their products; at the same time, companies will establish cooperation with the scientific sector and increase their own 
Tab. 1. SWOT analysis for the implementation of the BIZ-TRIZ mechanism

\begin{tabular}{|c|c|c|}
\hline SWOT & $\begin{array}{c}\text { POSITIVE FACTORS } \\
\text { FOR ACHIEVING THE OBJECTIVES OF THE BIZ-TRIZ } \\
\text { MECHANISM IMPLEMENTATION }\end{array}$ & $\begin{array}{c}\text { NEGATIVE FACTORS } \\
\text { FOR ACHIEVING THE OBJECTIVES OF THE BIZ-TRIZ } \\
\text { MECHANISM IMPLEMENTATION }\end{array}$ \\
\hline 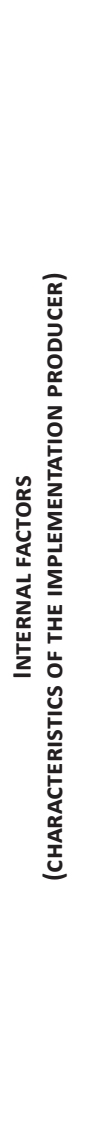 & $\begin{array}{l}\text { (S) Strong points } \\
\text { The strong reputation of the Maritime University of } \\
\text { Szczecin (MUS) in the research areas of transport, } \\
\text { mechatronics, machine construction and operation } \\
\text { and production engineering; } \\
\text { Experience of the Maritime University of Szczecin } \\
\text { in the implementation of activities popularising } \\
\text { the science of inventive creation and promoting } \\
\text { innovation (including co-organisation of the national } \\
\text { Design Thinking Week festivals in 2014, } 2015 \text { and } \\
\text { 2017, as well as supporting the Students' Research } \\
\text { Circle Innovator); } \\
\text { Experience of the Maritime University of Szczecin in } \\
\text { the implementation of research and R\&D projects; } \\
\text { The competent and committed scientific staff of the } \\
\text { Maritime University of Szczecin who have extensive } \\
\text { professional knowledge; } \\
\text { The competent and committed staff of the CTT } \\
\text { (Centre for Technology Transfer) in the Maritime } \\
\text { University of Szczecin with experience in R\&D } \\
\text { projects, knowledge transfer, commercialisation } \\
\text { of research results and protection of intellectual } \\
\text { property; } \\
\text { High-class research facilities at the Maritime } \\
\text { University of Szczecin (laboratories, workshops, } \\
\text { implementation of projects that bring the world of } \\
\text { science and business closer together }\end{array}$ & $\begin{array}{l}\text { - We Weak points } \\
\text { to the employees of the Maritime University of } \\
\text { Szczecin; } \\
\text { - The slogans "innovation", "innovativity" and } \\
\text { "commercialisation" are misunderstood among the } \\
\text { employees of the Maritime University of Szczecin } \\
\text { (when abused, they can become part of internal } \\
\text { jargon); } \\
\text { Researchers are distrustful and have conservative } \\
\text { attitudes towards the science of inventive creation/ } \\
\text { innovation/heuristics (they often perceive these } \\
\text { disciplines as parascientific); } \\
\text { Scientists have problems assimilating new } \\
\text { knowledge that breaks their routine approach, } \\
\text { habits, stereotypes and comfort zones; } \\
\text { The high cost of acquiring TRIZ competences (costs } \\
\text { of study visits, training and optional certification); } \\
\text { Lack of complete comprehension of the principles } \\
\text { of cooperation between researchers and external } \\
\text { stakeholders and the role of the CTT in this process; } \\
\text { Anxiety amongst scientists about the confrontation } \\
\text { with the real problems of recipients (SMEs) and the } \\
\text { need to start application-oriented research activities } \\
\text { (anxiety among scientists about making a mistake } \\
\text { and low utilisability of the research conducted so far) }\end{array}$ \\
\hline  & $\begin{array}{l}\text { (0) Opportunities } \\
\text { - Awareness of central authorities (Ministry of Science } \\
\text { and Higher Education) concerning the need to } \\
\text { improve relations between science and business; } \\
\text { The growing popularity of the use of heuristic and } \\
\text { invasive methods in solving complex problems (the } \\
\text { so-called wicked problems); } \\
\text { - Large market of potential buyers (companies from } \\
\text { the SME sector); } \\
\text { Growing market competitiveness makes it necessary } \\
\text { for SME companies to implement innovative } \\
\text { solutions to improve the position of the company; } \\
\text { The technological development of society requires } \\
\text { the use of systematic innovation methods (instead of } \\
\text { "blind" trial and error methods); } \\
\text { Difficult-to-solve technical problems increasingly } \\
\text { require the involvement of a multidisciplinary team } \\
\text { of specialists instead of a single expert }\end{array}$ & $\begin{array}{l}\text { (T) Threats } \\
\text { - Lack of financing for the Maritime University of } \\
\text { Szczecin from the Ministry of Science and Higher } \\
\text { Education; } \\
\text { Lack of understanding on the part of SMEs and the } \\
\text { related anxiety of cooperation between the company } \\
\text { and the university and the resulting risk that the } \\
\text { Maritime University of Szczecin will not find key } \\
\text { partners; } \\
\text { Lack of awareness by SMEs of the need to invest } \\
\text { in intellectual services (consulting, expertise, } \\
\text { commissioned work etc.); } \\
\text { Distrust and lack of willingness on the part of SMEs } \\
\text { to cooperate fully (fear or reluctance to disclose full } \\
\text { information about the problem). } \\
\text { Problems in communication between the scientific } \\
\text { community and entrepreneurs (lack of knowledge } \\
\text { of the rules of cooperation, "a different language" of } \\
\text { cooperation); } \\
\text { Surveys carried out on behalf of entrepreneurs will } \\
\text { not produce satisfactory results (will not solve the } \\
\text { problems or will have low commercial value) }\end{array}$ \\
\hline
\end{tabular}


Tab. 2. Main stakeholders in the implementation of the BIZ-TRIZ mechanism

\begin{tabular}{|l|l|}
\hline \multicolumn{1}{|c|}{ SYMBOL } & \multicolumn{1}{c}{ STAKEHOLDER } \\
\hline I1 & $\begin{array}{l}\text { The Ministry of Science and Higher Education - the Government of the Republic of Poland } \\
\text { A recognised TRIZ training and research Centre (e.g. ETRIA Berlin Institute) } \\
\text { I3 }\end{array}$ \\
A high-class specialist(s) of TRIZ, e.g. the TRIZ MASTER \\
I5
\end{tabular}

\begin{tabular}{|c|c|c|c|c|c|c|c|c|c|c|c|}
\hline \multirow{10}{*}{  } & 10 & & & & & & I1 & & & & I7 \\
\hline & 9 & & & & & & & & & 13 & I8 \\
\hline & 8 & & & & & & & & I9 & I6 & \\
\hline & 7 & & I5 & & & & & I2 & & & \\
\hline & 6 & & & & & & & & & & \\
\hline & 5 & & & & & & & & & & \\
\hline & 4 & & & & & I4 & & & & & \\
\hline & 3 & & & & & & & & I10 & & \\
\hline & 2 & & & & & & & & & & \\
\hline & 1 & & & & & & & & & & \\
\hline & & 1 & 2 & 3 & 4 & 5 & 6 & 7 & 8 & 9 & 10 \\
\hline
\end{tabular}

Fig. 3.Stakeholder matrix for the implementation of the BIZ-TRIZ mechanism

awareness of the need to invest in intangible advisory services and the creation of innovations, an awareness that is still undeveloped in Poland;

- I3 - world-class specialists of the 5th degree of the TRIZ MASTER (affiliated MATRIZ, MIT, etc.) and $\mathrm{I} 2-\mathrm{a}$ recognised training and research centre in the field of TRIZ (e.g. the ETRIA Berlin
Institute) will fulfil their "statutory task" to disseminate TRIZ, thus increasing social awareness amongst Poles that the methods of systematic innovation development are worth using and that their use is a powerful stimulator of innovation. 
- I6 - employees of the CTT of the Maritime University of Szczecin (the producer of the implementation) will establish fruitful cooperation and develop mechanisms of cooperation between science and business; the CTT will highlight the main objectives for which these units were created in Poland, and the awareness of which is very limited among Polish scientists;

- I9-individuals responsible for the management of the BIZ-TRIZ implementation at the Maritime University of Szczecin (the producer of the implementation) will gain new experience and competences in the field of innovative project management, at the same time they will establish fruitful international and local cooperation focused on the implementation of further joint ventures with business;
- I1 - institutions co-financing research and the Government of the Republic of Poland will implement planned activities aimed at overcoming obstacles on the path of science and business (which are still very significant), directing scientific research to the needs of the Polish market, stimulating the pro-innovative activity of Polish scientists and intensifying activities aimed at putting Polish society on the track leading to a knowledge-based economy.

\section{RISK ASSESSMENT}

Based on the results obtained from the stakeholder analysis, the risk associated with the implementation of the BIZ-TRIZ mechanism was analysed.

Tab. 3. Identification of the risks related to the implementation of the BIZ-TRIZ mechanism

\begin{tabular}{|c|c|c|c|c|}
\hline No. & RISK & SOURCE & EFFECTS & $\begin{array}{c}\text { THE PROB- } \\
\text { ABILITY OF } \\
\text { OCCUR- } \\
\text { RENCE } \\
\end{array}$ \\
\hline 1 & A lack of external financing & $\mathrm{E}$ & $\mathrm{C}$ & M \\
\hline 2 & Exceeding the budget for the BIZ-TRIZ implementation & $\mathrm{I}+\mathrm{E}$ & $\mathrm{S}$ & VL \\
\hline 3 & A lack of entrepreneurs, preventing timely implementation & $\mathrm{E}$ & $\mathrm{C}$ & M \\
\hline 4 & $\begin{array}{l}\text { Problems encountered by scientists regarding the acquisition of TRIZ } \\
\text { knowledge }\end{array}$ & I & $\mathrm{S}$ & M \\
\hline 5 & $\begin{array}{l}\text { Mistakes during the preparation of the technical appraisal (research work on } \\
\text { behalf of entrepreneurs) }\end{array}$ & $I+E$ & S & $\mathrm{L}$ \\
\hline 6 & A lack of data for the drafting of a full technical appraisal for entrepreneurs & $E$ & M & $\mathrm{L}$ \\
\hline 7 & $\begin{array}{l}\text { Problems in cooperation/communication between the scientific community } \\
\text { and entrepreneurs (a lack of knowledge of the cooperation rules) }\end{array}$ & $I+E$ & $\mathrm{~S}$ & M \\
\hline 8 & $\begin{array}{l}\text { Low utilisation of the performed research (fear among scientists regarding the } \\
\text { fit of the solution to real problems) }\end{array}$ & I & $\mathrm{S}$ & $\mathrm{L}$ \\
\hline 9 & $\begin{array}{l}\text { Surveys made for entrepreneurs will not produce satisfactory results (will not } \\
\text { solve problems identified by the entrepreneurs) }\end{array}$ & $I+E$ & M & $\mathrm{L}$ \\
\hline 10 & Execution of the contracts for entrepreneurs will be longer than scheduled & $I+E$ & S & M \\
\hline 11 & $\begin{array}{l}\text { As a result of the implementation, solutions of low commercial value will be } \\
\text { created }\end{array}$ & $\mathrm{I}+\mathrm{E}$ & $\mathrm{N}$ & $M$ \\
\hline 12 & $\begin{array}{l}\text { The qualifications of the contractors may not be sufficient to solve the } \\
\text { problem and it will be necessary to expand the team to include additional } \\
\text { people who have not yet been trained in TRIZ }\end{array}$ & $I+E$ & C & $M$ \\
\hline
\end{tabular}

Source: internal (I), external $(E)$

Effects: critical $(C)$, big $(B)$, moderate $(M)$, negligible $(N)$

Probability of occurrence: very high $(\mathrm{VH})$, high $(H)$, medium $(M)$, low $(L)$, very low $(V L)$ 
For particular risks, actions to prevent and minimise them have been proposed. The risk analysis has been developed considering the main objective: which is to strengthen cooperation between universities (Maritime University of Szczecin) and SME-type enterprises by providing services for these enterprises. The following analysis is synthetic in nature and does not include a detailed description of the planned activities within the framework of risk management of the implementation of BIZ-TRIZ.

Tab. 3 presents threats for the achievement of the identified objectives through the implementation of

\begin{tabular}{|c|c|c|c|c|c|}
\hline & VL & L & M & H & VH \\
\hline C & & & $1,3,12$ & & \\
\hline B & 2 & 5,8 & $4,7,10$ & & \\
\hline $\mathrm{M}$ & & 6,9 & 11 & & \\
\hline $\mathrm{N}$ & & & & & \\
\hline
\end{tabular}

Fig. 4. Risk matrix for the implementation of the BIZ-TRIZ mechanism all the tasks provided in the project. For each hazard, the effects were classified as critical (C), significant $(\mathrm{S})$, moderate $(\mathrm{M})$, low $(\mathrm{N})$ and the probability of each hazard occurring was determined using expert knowledge and the available statistics, which were classified as a probability: very high $(\mathrm{VH})$, high $(\mathrm{H})$, medium (M), low (L) and very low (VL).

The executors of the BIZ-TRIZ implementation have several tools that allow for effective management of the identified risks. The vast majority of risks can be eliminated or reduced during the preparation phase of the BIZ-TRIZ implementation. The implementation operator has the greatest impact on the threats of an internal nature, although it may indirectly affect the mitigation of negative external effects. For each of the identified threats, a risk matrix for the implementation has been prepared, which can be seen in Fig. 4.

The risk matrix shows that there is a group of acceptable threats that only require monitoring (the lower left corner of the matrix) and a group of threats that require preventive and compensatory action (the upper right corner of the matrix). According to the adopted classification, the hazards numbered 2, 5, 6, 8,9 and 11 were classified in this first group. The actions foreseen for the remaining risks are summarised in Tab. 4.

Tab. 4. Risk minimisation and prevention in the implementation of the BIZ-TRIZ mechanism

\begin{tabular}{|c|c|c|}
\hline No. & RISK & PREVENTIVE/COMPENSATORY ACTION \\
\hline 1 & A lack of external financing & $\begin{array}{l}\text { - A very well-prepared application form. The fulfilment of competition } \\
\text { requirements for external financing }\end{array}$ \\
\hline 3 & $\begin{array}{l}\text { A lack of entrepreneurs will prevent } \\
\text { timely implementation. }\end{array}$ & $\begin{array}{l}\text { - The CTT promoting engagement (searching for partners during business } \\
\text { breakfasts, cooperation exchanges and making direct contacts); } \\
\text { - } \quad \text { A well-prepared contract with companies; } \\
\text { Good communication between partners (adherence to the agreed rules of } \\
\text { cooperation) }\end{array}$ \\
\hline 4 & $\begin{array}{l}\text { Problems encountered by scientists } \\
\text { regarding the acquisition of TRIZ } \\
\text { knowledge }\end{array}$ & $\begin{array}{l}\text { - The implementation of training courses, study visits and case studies under } \\
\text { the supervision of recognised TRIZ specialists (mentoring by MATRIZ certi- } \\
\text { fied specialists) }\end{array}$ \\
\hline 7 & $\begin{array}{l}\text { Problems in cooperation/ } \\
\text { communication between the scientific } \\
\text { community and entrepreneurs (the lack } \\
\text { of knowledge of the cooperation rules) }\end{array}$ & $\begin{array}{l}\text { - } \quad \text { Promotion by the CTT; } \\
\text { - } \quad \text { G well-prepared contract with companies; } \\
\text { cooperation) }\end{array}$ \\
\hline 10 & $\begin{array}{l}\text { Execution of contracts for } \\
\text { entrepreneurs will be longer than } \\
\text { scheduled }\end{array}$ & $\begin{array}{l}\text { - The continuity of the execution of implementation tasks. } \\
\text { - } \quad \text { Appropriate planning and supervision of the implementation of individual } \\
\text { - } \quad \text { Porks commissioned for entrepreneurs by the manager; } \\
\quad \text { Possible revision of the implementation schedule }\end{array}$ \\
\hline 12 & $\begin{array}{l}\text { The qualifications of the contractors } \\
\text { may not be sufficient to solve the } \\
\text { problem and it may be necessary to } \\
\text { expand the team to include additional } \\
\text { people who have not yet been trained } \\
\text { in TRIZ }\end{array}$ & $\begin{array}{l}\text { - Training a team member in the scope of competences and authorisations to } \\
\text { carry out further training (level } 3 \mathrm{MATRIZ);} \\
\text { Expanding the team with additional specialists required for the implementa- } \\
\text { tion of a specific research service; } \\
\text { Training of additional team members in-house by a team member who has } \\
\text { previously obtained appropriate competences and authorisations to con- } \\
\text { duct further training (level } 3 \text { MATRIZ) }\end{array}$ \\
\hline
\end{tabular}


In the close vicinity of the producer of the implementation, a large number of potential customers were found by the CTT, starting in 2014 since it started organising business breakfasts and co-organising cooperative science-business exchanges in the West Pomeranian Voivodeship. These efforts made the risk of failure in achieving the implementation assumptions relatively low. Nonetheless, if such a situation occurs, preventive actions may be taken in the form of the customer searching in more remote areas (e.g. through networks operating for enterprises, e.g. PARP (the Polish Agency for Enterprise Development) and other CTTs, special-purpose companies or the Top 500 Innovators Association).

\section{DISCUSSION}

The results obtained from the analyses presented in this paper show that the implementation of the BIZ-TRIZ mechanism may contribute to the identified obstacles being overcome in the cooperation between university and business entities using the opportunities and strengths of the universities listed in Tab. 1.

The implemented BIZ-TRIZ mechanism will significantly contribute to the delivery of assumptions required for the knowledge-based economy by showing SMEs the possibility of creating innovations in cooperation with science and thus potentially increase the competitiveness of these enterprises. During implementation, the working groups will conduct scientific research on three levels of activity:

- The development of specific analytical tools based on the knowledge of the disciplines represented by team members (materials engineering, machine construction and operation, electrical engineering, etc.) (Chybowski \& Gawdzińska, 2016a; Chybowski \& Gawdzińska, 2016b) and general system models provided by TRIZ;

- Sub-studies, research and technical reports and the implementation of stages related to the solution of problems reported by companies from the SME sector (diagnosis of the problem and preparation of proposals for its solution) (Gawdzińska et al., 2017; Wiśnick et al., 2017a; Wiśnicki et al., 2017b);

- The collection of partial data from case studies (orders for SMEs) and the evaluation of the implementation, which will enable the development of new cooperation models for universities and businesses, the evaluation of the usefulness of inventive methods in the realities of the Polish economy and lessons learned that stemmed from the effects of the implementation of BIZ-TRIZ.

The implementation of the mechanism will also demonstrate to entrepreneurs that it is worth investing in research services provided by the scientific sector and that innovations can even be introduced in small companies. In turn, scientists will find that, by working with other professionals and with the SME sector, they will be able to provide solutions that are useful to society.

Potentially, the detailed tangible effects of the implementation of the BIZ-TRIZ mechanism will be:

- Increased awareness by entrepreneurs and scientists of the possibility to effectively cooperate (including after the implementation of the BIZTRIZ mechanism);

- A unique workshop for the scientific staff of the producer of the implementation that will allow them to use their profound and extensive scientific knowledge to systematically create innovations (including after the implementation of the BIZ-TRIZ mechanism);

- The formation of multidisciplinary working teams of the producer of the implementation as a result of the implementation of the BIZ-TRIZ mechanism, which will create the potential for similar activities to be carried out after the implementation of the BIZ-TRIZ mechanism;

- The acquisition by scientific employees, of the producer of the implementation, of valuable experience and competences to build their scientific careers and to obtain degrees and titles based on cooperation with the local economy;

- The expansion of the contacts of the producer of the implementation with the business community (SME database);

- The expansion of the portfolio of the producer of the implementation as an entity that can effectively cooperate with business entities (success stories);

- The development of tools for effective technology transfer by the CTT for the producer of the implementation.

\section{CONCLUSIONS}

Through the practical use of TRIZ and the dissemination of the results, the BIZ-TRIZ mechanism 
will significantly contribute to the dissemination of the methodology in the Polish economy. The promotion of the systematic creation of innovations (TRIZ) and inventions should be a priority for the authorities that want to improve Poland's position in international innovation rankings.

The results of the BIZ-TRIZ implementation and the applied solutions should be popularised in several following ways: the publishing of books and scientific and popular articles (e.g. in magazines for entrepreneurs), the participation in conferences and thesis defence presentations for the award of scientific degrees to participants of the implementation. Such an approach would make it possible to use the effects of the implementation for other scientific entities and SMEs and would strengthen the position of the producer of the implementation as a pro-innovation university, which can provide tailor-made solutions for entrepreneurs.

The main limitations on the BIZ-TRIZ implementation are financial, because entrepreneurs have to cover the costs of the commissioned R\&D works. The analysis presented in the article revealed significant possibilities and potential benefits from the implementation of the BIZ-TRIZ mechanism. The next proposed stage is the preparation of a project that will be financed by external sources, which is intended to implement the mechanism in practice. The university will also provide $\mathrm{R} \& \mathrm{D}$ services to entrepreneurs. A possible approach would be to select entrepreneurs by way of a competition. A favourable implementation of such a project and the dissemination of knowledge about benefits received by participating companies will possibly become the basis for the further development and use of the BIZ-TRIZ mechanism for the commercial resolution of problems encountered by entrepreneurs, so that the university would be able to increase its share in the implementation of research work for local companies.

\section{ACKNOWLEDGEMENTS}

The research presented in this article was carried out under the Grant No 1/S/IESO/17 of the Ministry of Science and Higher Education of Poland "Increasing operational effectiveness of complex technical systems by the systematic development and implementation of innovations using novel materials and modifying the object's structure" implemented at the Maritime University of Szczecin, Poland.

\section{LITERATURE}

Boratyński, J. (2013). TRIZ dla ciekawych. Ciekawi świata sa ludzie młodzi! [TRIZ for the curious. Young people are curious about the world!]. Kielce, Poland: Urząd Marszałkowski Województwa Świętokrzyskiego, Sagalara.

Cempel, C. (2013). Inżynieria kreatywności w projektowaniu innowacji [Creativity engineering in innovation design]. Radom - Poznań, Poland: ITE.

Chybowska, D., Chybowski, L., \& Souchkov, V. (2018a). Is Poland an innovative country? Management Systems in Production Engineering, 26(1), 35-41. doi: 10.2478/ mspe-2018-0006

Chybowska, D., Chybowski, L., \& Souchkov, V. (2018b). R\&D in Poland: Is the Country Close to a Knowledge-Driven Economy? Management Systems in Production Engineering, 26(2), 99-105. doi: 10.1515/mspe-2018-0016

Chybowski, L. (2018). Use of TRIZ Su-Field models in the process of improving the injector of an internal combustion engine. MAPE - Multidisciplinary Aspects of Production Engineering. Proceedings of XV International Conference Multidisciplinary Aspects of Production Engineering, 1(1), 257-268. doi: 10.2478/ mape-2018-0033

Chybowski, L., \& Chybowska D. (2016b). Metody tworzenia innowacyjnych rozwiązań technicznych Wykorzystanie zasobów informacyjnych [Methods of creating innovative technical solutions - Use of information resources]. Industrial Monitor Produkcja i Utrzymanie Ruchu, 2(20), 30-32.

Chybowski, L., \& Chybowska, D. (2016a). Metody tworzenia innowacyjnych rozwiązań technicznych - FOS, czyli poszukiwania zorientowane na funkcję [Methods of creating innovative technical solutions - FOS - function-oriented research]. Industrial Monitor - Produkcja i Utrzymanie Ruchu, Q1(19), 44-45.

Chybowski, L., \& Gawdzińska, K. (2016a). On the Possibilities of Applying the AHP Method to a Multicriteria Component Importance Analysis of Complex Technical Objects. Advances in Intelligent Systems and Computing, 445, 701-710. doi: 10.1007/978-3319-31307-8_71

Chybowski, L., \& Gawdzińska, K. (2016a). On the Present State-of-the-Art of a Component Importance Analysis for Complex Technical Systems. Advances in Intelligent Systems and Computing, 445, 691-700. doi: 10.1007/978-3-319-31307-8_70

Chybowski, L., \& Idziaszczyk D. (2015b). Metody tworzenia innowacyjnych rozwiązań technicznych - TRIZ Teoria Rozwiązywania Innowacyjnych Zagadnień [Methods of creating innovative technical solutions - TRIZ - Theory of Inventive Problem Solving]. Industrial Monitor - Produkcja i Utrzymanie Ruchu, Q2(16), 40-44.

Chybowski, L., \& Idziaszczyk, D. (2015a). Metody tworzenia innowacyjnych rozwiązań technicznych - brainstorming, czyli burza mózgów [Methods of creating innovative technical solutions - brainstorming or brainstorming]. Industrial Monitor - Produkcja i Utrzymanie Ruchu, Q4(18), 43-45.

Chybowski, L., \& Idziaszczyk, D. (2015c). $\mathrm{O}$ antropocentrycznym i technocentrycznym 
podejściu w procesie tworzenia innowacji [Anthropocentric and technocentric approach to the innovation process]. In J. Brodny, \& Ł. Dziemba (Eds.). Systemy Wspomagania w Inżynierii Produkcji. Inżynieria Systemów Technicznych [Assistive Systems in Production Engineering. Engineering of Technical Systems], (pp. 51-63). Gliwice, Poland: P.A. NOVA.

Chybowski, L., Gawdzińska, K., \& Przetakiewicz, W. (2017). AHP based multi-criteria function analysis as a TRIZ tool for complex technical systems. Proceedings of the 13th MATRIZ TRIZfest 2017 International Conference, 31-45.

European Comission. (2018). European Innovation Scoreboard 2018 Europe must deepen its innovation edge. Retrieved from https://ec.europa.eu/growth/ content/european-innovation-scoreboard-2018europe-must-deepen-its-innovation-edge_en

Gawdzińska, K., Chybowski, L., Przetakiewicz, W., \& Laskowski, R. (2017). Application of FMEA in the Quality Estimation of Metal Matrix Composite Castings Produced by Squeeze Infiltration. Archives of Metallurgy and Materials, 62(4), 2171-2182. doi: 10.1515/amm-2017-0320

Półkoszek, A. 2016. Wycena technologii. Materiały szkoleniowe. BOMIS, Poznań.

Powell, W. W., \& Snellman, K. (2004). The Knowledge Economy. Annual Review of Sociology, 30, 199-220. doi: 10.1146/annurev.soc.29.010202.100037

Souchkov, V. (2015). Typical Patterns of Business Model Innovation. The Journal of the European TRIZ Association, Special Issue: Collection of papers of 15th International TRIZ Future Conference - Global Structured Innovation, 121-127.

Souchkov, V. (2017). Online TRIZ Training: Experience with Development and Delivery. Proceedings of the 13th International Conference TRIZfest 2017, 287294.

Souchkov, V., \& Roxas, J. P. (2016). A System of Standard Inventive Solution Patterns for Business and Management problems. Proceedings of the 12th International Conference TRIZfest 2016. The International TRIZ Association - MATRIZ, 22-35.

Wiśnicki, B., Chybowski, L., \& Czarnecki, M. (2017a). Analysis of the efficiency of port container terminals with the use of the Data Envelopment Analysis method of relative productivity evaluation. Management Systems in Production Engineering, 1(25), 9-15. doi: 10.1515/mspe-2017-0001

Wiśnicki, B., Milewski, D., Chybowski, L., \& Hełczyński, I. (2017b). The Concept of the Development of Intermodal Transport Network Illustrated by Polish Market, Naše More, 64(1), 33-37. doi: 10.17818/ $\mathrm{NM} / 2017 / 1.6$

Yatsunenko, S., \& Karendał, P. (2016). Teoria Rozwiązywania Innowacyjnych Zadań - kontrolowany sposób tworzenia innowacji [Theory of Inventive Problem Solving - a controlled way to create innovation]. Retrieved from http://www.pi.gov.pl/PARP/ 